\title{
Geospatial Information and One Map Policy: Challenges and Opportunities in Innovation and Competitiveness of Entrepreneurship of Industrial Revolution 4.0
}

\author{
Sugianto Sugianto ${ }^{1}$, Hendra Syahputra ${ }^{2}$, Muhammad Rusdi ${ }^{3}$, and Muhammad Iqbal ${ }^{4}$ \\ ${ }^{1}$ Remote Sensing and Cartographic Laboratory, Soil Science Department, Syiah Kuala \\ University \\ ${ }^{2}$ Ar Raniri Islamic State University, Banda Aceh Indonesia \\ ${ }^{3}$ Soil Science Department, Syiah Kuala University \\ ${ }^{4}$ Alumnae Syiah Kuala University \\ $\left\{{ }^{1}\right.$ sugianto@unsyiah.ac.id\}
}

\begin{abstract}
More and more businesses are looking for types of data and the analysis of new forms in order to remain competitive in running their business. Various innovations have been and continue to be developed in an attempt to extend the reach of market places and also to take advantage of existing data sources including lately using geospatial data. On the other hand, the government of Indonesia in 2016 has introduced one map policy. The use of geospatial data and one map policy are a form of synergy in creating digital innovations and development entrepreneurship. This article presents a study related to the use of geospatial data and the one map policy in creating opportunities and challenges of innovation and development of the entrepreneurship. The use of geospatial data can bring up an important source of information in both traditional data analysis as well as data analysis. Geospatial data analysis tool to synergize with other data that can be integrated with product analysis and business innovation development opportunities, allowing the users this data will continue to evolve. The enactment of a policy map and the use of geospatial data available will create economic efficiency and will simplify the process of licensing effort because the geographic and location information, i.e. geocoding can be easily obtained. The reference base map as the basis for decision policy will improve the accuracy of location-related information from a variety of economic activities. This condition will provide certainty in an attempt, by itself will create new entrepreneurship in order to anticipate the industry disruption 4.0. era
\end{abstract}

Keywords: Innovation, Geospatial Data, One Map Policy, Entrepreneurship.

\section{Introduction}

More and more businesses are looking for different types of data and the analysis of new forms in order to remain competitive in running their business, including the use of geospatial data. In the last two decades, thematic mapping of Earth surface has undergone a revolution as the result of advances in geographic information science and remote sensing, combined with Global positioning system (GPS), it usually called as geospatial technology. Geospatial technology has developed rapidly and is widely used for various purposes of which it related to 
geographic location. This article presents the results of a review and thoughts related to geospatial technology in innovation business in the Industry Revolution 4.0 [1]. The industry Revolution 4.0 is characterized by a fusion of technologies that is blurring the lines between the physical, digital, and biological spheres [2]

Eighty percent of current information related to spatial or geographic component and research shows that approximately $80 \%$ of all decisions in the public sector are based on dereferenced data [3]. This means that all information related to the location or place of geographical position or spatial data and it can be treated as an entity that can be managed using geospatial technology. It cannot be denied that the utilization of geospatial data currently entering an era of not very rapidly, not only limited to utilization to the field of geography, however other fields especially on the areas related to the utilization of natural resources and territorial.

Business one of the fields that utilize geospatial data needs to realize that the ease of access to information will make it easier for geospatial data in planning the deployment location of business, understand the spatial location associated with the form region, the infrastructure that has been built, proximity to markets that can distance is calculated, and the landscape of the region which will add more detailed information about the location. Another advantage that geospatial data can be updated in real-time.

Integration of remote sensing data and geographic information systems (GIS) which is the main component in the geospatial technology has a very good ability in visualizing geospatial data. The elements contained on the surface of the earth can be decomposed into several layers or geospatial data coverage. This layer with the surface of the earth can be reconstructed again or modeled in the form of the real three-dimensional world [4].

\section{1 geospatial technology for business and marketing, is it benefit?}

A popular use for geospatial analysis in marketing is segmentation of the market. The market in the era industrial Revolution 4.0 is facing a challenge. The challenge is how we can get benefited from it. The geospatial technology could answer this question, for example, if we run a business related to the location the goal is to divide customers into groups with common characteristics (unique). These customers may have demographic data (i.e., gender, income) and/or lifestyle and even behavior (i.e., buy) the same features. The goal is to use this segment to help improve promotion and retention, and to get new customers. For example, imagine a sports goods company that uses demographic data such as age, gender, and income, together with a history of purchases, to develop the rest. By analyzing this data, the company has identified the target segments and what innovation can be made.

In geospatial technology, one can add to the mix a geospatial data that can help companies maximize promotional activities and target new customers. The company can enrich the collection of data using data geocode from the zip code associated with your current customers (e.g., information from loyalty cards) to help visualize the place customers in this segment. A map that combines this data along with the location of the store help companies visualizes the distribution of target segments around his shop to see costumers clustered geographically. If so, the business analyst can create new derivative variables are called range, i.e. the distance between zip codes and a variety of store location [5].

The company can then look for another woman (using third-party data) that meet the profile of the segment and is in a group within a 15-mile radius from the shops. Retailers can then determine which stores will benefit from promotion-targeted. In general, geospatial technology can improve the management of assets to facilitate the law enforcement agencies to sharpen the risk analysis, expand transportation planning and logistics, and to sharpen the strategic location 
determination. Various types of geospatial technologies that can contribute to innovation in the business to meet industry 4.0 era [6].

1) Remote sensing Data-image data is collected from a camera or sensor platforms space or air. Some commercial satellite imagery provider offers high-resolution images even to less than a meter which can be used to monitor the area in more detail.

2) Geographic information systems (GIS): a series of software for mapping and analysis of georeferenced data on the Earth's surface, otherwise known as geospatial data and others.

3) Global Positioning System (GPS) satellite network: who can give you the exact coordinates of the location to the civil and military users with the proper receiver equipment.

4) Internet Mapping Technologies: software programs such as Google Earth and web features like Microsoft Virtual Earth changed

As illustrated in figure 1, the geospatial technology will encompass all aspects of the business with geospatial reference.

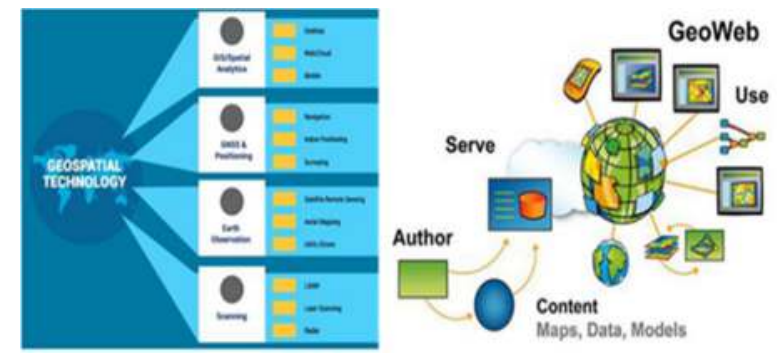

Figure 1. Geoweb and Geospatial Technology coverage

Source:.https://www.geospatialworld.net/wp-content/uploads/2017/02/jyostnas-blog.jpg. https://www.geospatialworld.net/wp-

\section{2 one map policy, government of indonesia}

The Government in the near future will publish a policy map (one folder policy). One policy map integrating 85 thematic map that had the responsibility of 19 ministries and agencies. This policy starts from the publication of presidential Regulation (Regulation) number 27 years 2014 National Geospatial Information about the network (JIGN). This President Decree then followed the publication of the Regulation No. 9 the Year 2016 on the acceleration of the implementation of the policy on One Map at the level of accuracy of a map scale of 1:50,000.

One policy map would make the overall economic activities become more efficient. Even with this, there is one map, will facilitate the process of licensing effort. This makes the popular indexes such as the ease of doing business (EODB) or ease of trying also helped. Based on the accuracy of the data, these policies can reduce overlapping granting permission that is often the cause of conflicts. "One map can be likened to such infrastructure in drawing up the policy. The existence of a single map, policy formulation including related licensing decisions can be based on data that is accurate, "said the Deputy President's Staff Office II Republic on Indonesia, Yanuar Nugroho. The same map reference base will improve the accuracy of location-related information from a variety of economic activities. This condition will provide certainty in business. "Evidence or geospatial information that is either expected to be able to help the Government in granting time pruning different types of licensing," he added. With a single 
policy map expected logistics pertaining to distance, space and infrastructure can be more efficient. In addition, the logistics performance index ranked Indonesia also expected could be going up.

According to the World Bank Group (2018) [7] that there are five pillars of a policy map. First, data utilization regulations related policies for the benefit of investment and location information. This is to avoid overlapping land use permits. "The second pillar is the institutional readiness for ministries and agencies as well as local government geospatial information dissemination in order. The third pillar of the technology, how to connect to geoportal, "said he. The fourth pillar is not less important are the pillars of the standard to ensure that the required data and will be used meets the national standards. The fifth pillar is the readiness of the human resources (HR) in order to operate and utilize every available data in one policy map. The four pillars will not be the way. When are the quality and quantity of baseball there is a human resource? Approximately 20,000 HR required for geospatial. Without a strong Human Resources later ruled a foreigner, "he said. What does the impact of this policy on the entrepreneurship and innovation? The impact will be a challenge that the government will release the regulation to ease the business to get access to the spatial data in the form of more detail scale. A businessman can identify easily the location and potential business will be created.

\section{Business Intelligent}

Another development in business development using geospatial data-what it is called a Business Intelligent [8]. Business intelligent is a technology-driven process for analyzing data and presenting actionable information to help executives, managers, and other corporate end users make informed business decisions. Business Intelligence is a widely used management term which refers to the applications and technologies available that gather and analyses data about the company's operations. Managers are therefore able to make more informed decisions about the current and future aspects of the company by understanding historical trends and operations. Geospatial data is usually used to define data and the associated technology that has a geographic or locational component - such as coordinates, address, city or postal code. Combination of Geospatial data with Business Intelligence, we may improve decision making which can lead to new revenue opportunities, improved cost visibility, and better risk management. There are many systems and sensors on the market that can capture geospatial information - we believe that the real value lies in the end result - this is why we sell solutions and not just products. 3D Laser Mapping, for example, is committed to helping customers be successful.

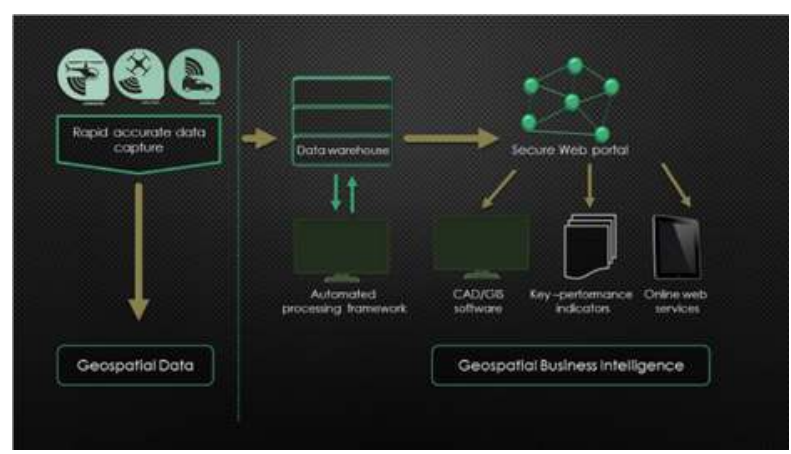

Figure 2: Flow chart of Business Intelligent Process [9]. 


\section{Challenges And Opportunities}

The Fourth Industrial Revolution has the potential to raise global income levels and improve the quality of life for populations around the world. However, the question to be raised is how prepared we are in facing this era. To date, those who have gained the most from it have been consumers able to afford and access the digital world; technology has made possible new products and services that increase the efficiency and pleasure of our personal lives. To date, for example, booking a flight, buying a product, making a payment, listening to music, watching a film, or playing a game - any of these can now be done remotely, and it using technology that support geographic location.

The challenge in the future is, can technological innovation will also lead to a supply-side miracle with long-term gains in efficiency and productivity? Transportation and communication costs will drop, logistics and global supply chains will become more effective, and the cost of trade will diminish, all of which will open new markets and drive economic growth. As we realize that the Industrial Revolution 4.0 will also profoundly impact the nature of national and international security, affecting both the probability and the nature of the conflict. The history of warfare and international security is the history of technological innovation, and today is no exception.

Neither technology nor the disruption that comes with it is an exogenous force over which humans have no control. All of us are responsible for guiding its evolution, in the decisions we make on a daily basis as citizens, consumers, and investors. We should thus grasp the opportunity and power we have to shape the Industrial Revolution 4.0 and direct it toward a future that reflects our common objectives and values.

The challenge facing related geospatial technologies for current utilization is the readiness of the human resources and technologies that can propel an acceleration in creating entrepreneurship in accordance with the demands of national development within the mission of long-term national development 2015-2025. There are several points that can be expressed in the utilization of geospatial data for the acceleration of the development and business development among other related Geospatial Business: planning the future, utilization of Geospatial Data in the entrepreneurship and innovation-based spatial data. To meet the above challenges, the necessary studies related to the utilization of geospatial technologies.

\section{Conclusion}

Geospatial data analysis tool to synergize with other data that can be integrated with product analysis and business innovation development opportunities, allowing the users this data will continue to evolve. The enactment of a policy map and the use of geospatial data available will create economic efficiency and will simplify the process of licensing effort because the geographic and location information, i.e. geocoding can be easily obtained. The reference base map as the basis for decision policy will improve the accuracy of location-related information from a variety of economic activities. This condition will provide certainty in an attempt, by itself will create new entrepreneurship in order to anticipate the industry disruption 4.0. era.

\section{REFERENCES}

[1] M. Hermann, T. Pentek, and B. Otto, "Design principles for industrie 4 . 0 scenarios: A literature review working paper a literature review,” 2016, no. 49th Hawaii International 
Conference on System Sciences (HICSS), pp. 3928-3937.

[2] M. Bonner, "What is industry 4.0 and what does it mean for my manufacturing?," Saint Clair Systems Norcross Temperature and Viscocity Control, 2017. [Online]. Available: https://blog.viscosity.com/blog/what-is-industry-4.0-and-what-does-it-mean-for-mymanufacturing.

[3] J. Riecken, "The improvement of the access to public geospatial data of cadastral and surveying and mapping as a part of the development of a NSDI in Northrhine-Westfalia Germany," in 4th AGILE Conference on GIScience, 2001, pp. 215-221.

[4] P. D. Rahardjo, "Teknik penginderaan jauh dan sistem informasi geografis untuk identifikasi potensi kekeringan," Makara, Teknol., vol. 14, no. 2, pp. 97-105, 2010.

[5] M. A. Wahab, R. R. Ali, E. F. Essa, and M. A. El Semary, "Land information database for the optimum use of the newly reclaimed soils," Middle East J. Appl. Sci., vol. 5, no. 4, pp. 992-995, 2015.

[6] Sugianto, "Pemanfaatan teknologi geospasial untuk percepatan pembangunan infrastruktur sumberdaya air dan konstruksi," in Seminar Nasional Pendidikan Kedinasan, 2017.

[7] World Bank Group, "Growing smarter: Learning \& equitable development in East Asia Pacific," The World Bank, 2018. [Online]. Available: https://www.worldbank.org/en/region/eap/publication/growing-smarter-learningequitable-development-in-east-asia-pacific.

[8] S. Negash, "Business intelligence," Commun. Assoc. Inf. Syst., vol. 13, no. February, pp. 177-195, 2004.

[9] H. Brewitt, "What is geospatial business intelligence?," Geoslam, 2016. [Online]. Available: https://geoslam.com/blog-post/what-is-geospatial-business-intelligence/. 